\title{
Retrofitting on Flexural Strength of RC Columns Using Polyester Resin Concrete
}

\author{
Dahlia Patah \\ Civil Engineering Department, West Sulawesi University, Majene, INDONESIA \\ dahliapatah@unsulbar.ac.id \\ Ashar Saputra \\ Department of Civil and Environmental Engineering, Universitas Gadjah Mada, Yogyakarta, INDONESIA \\ ashar@tsipil.ugm.ac.id \\ Andreas Triwiyono \\ Department of Civil and Environmental Engineering, Universitas Gadjah Mada, Yogyakarta, INDONESIA \\ ahdreac@tsipil.ugm.ac.id
}

\begin{abstract}
Concrete column structures damages due to flexural moment need to be repaired and strengthened to avoid of sudden failure by applying appropriate methods. The method applied in this study was retrofitting by applying polyester resin concrete. In order to know the effect of polyester resin concrete against axial load capacity, stiffness, ductility and the damage pattern of columns by eccentrically loaded, an experimental laboratory was carried out. In this study, three column specimens are tested. The dimension of the specimen is $150 \mathrm{~mm} \times 150 \mathrm{~mm}$ and the high of the column are $1200 \mathrm{~mm}$ with the effective high is 600 $\mathrm{mm}$ and $600 \mathrm{~mm}$ for corbel. The column specimens have a fixed eccentricity of $50 \mathrm{~mm}$. First, initial column tested before yield point of reinforcing bar reached and concrete crack limited to $0,4 \mathrm{~mm}$. Further, retrofitting applied to each initial column specimen using normal concrete and polyester resin concrete with the level of resin $15 \%$ and $20 \%$, respectively. Retrofitting column tested again with the same loading of initial column until it reaches the collapse load. The result of experiment compares to analysis method by Nawy and Whitney which represent the analysis of normal concrete column capacity. The result showed that levels of resin to be used is $20 \%$ because of better workability compared to $15 \%$ resin. Further, compressive test on resin concrete cylinder showed that the resin level at $15 \%$ and $20 \%$ are $82.82 \mathrm{MPa}$ and $76.65 \mathrm{MPa}$, respectively. The strength of KR-ii decreased about 33.523\%. The strength of KR-15ii and KR-20ii increased 5.08\% and 24.827\% respectively compared to initial column. Specimen column stiffness KR-ii. KR-15ii and KR-20ii decreased about 76.22\%, $24.50 \%$ and $37.65 \%$, respectively from the initial column. Furthermore, ductility of KR-ii, KR-15ii and KR-20ii decreased about $1.512,1.250$ and 2.50, respectively. The changes of the ultimate capacity load of KR-ii, KR-15ii and KR-20ii by Nawy Method respectively $-26.54 \%, 12.66 \%$, and $13.83 \%$, whereas the method of Whitney respectively $-17.68 \%, 26.25 \%$, and $27.56 \%$. The use of polyester resin concrete can change the pattern of collapse from brittle to ductile columns.
\end{abstract}

Keywords: retrofit, ductility, stiffness, flexural column, eccentricity

\section{INTRODUCTION}

Column is one of the important components from a structure building to support of flexural moment, axial load and lateral load. The presence of eccentricity load, will also cause the column to support combination load from press load and flexural load. When the building components, especially the columns that have been flexural failure will be enabled again, then should be retrofitting of flexural strength is required. One of the methods used in this study by retrofitting of concrete columns using polymer or resin concrete. Polyester resin concrete is is made from a mixture of coarse and fine aggregates with polyester resin. Although the costs for the manufacture of polyester resin concrete is more expensive than normal concrete, polyester resin concrete has high compressive strength, high elastic modulus, high tensile strength, low creep, high thermal stability, high humidity resistance, hardening time can be arranged. The polyester resin concrete can also increase the flexural capacity of the column strength, and change the pattern of collapse of the brittle to ductile columns. Dimensional architecture can be maintained if the actual load is larger than the initial load since the polyester resins concrete compressive strength greater than normal one.

The objective of this study is to determine the right composition when making polyester resin concrete, in 
order to know the mechanical properties of polyester resin concrete $15 \%$ and $20 \%$, in order to know the changes in axial load capacity, stiffness, ductility, comparing with the experimental ultimate load analysis by Nawy's Method and Whitney's Method, as well as knowing the pattern collapse reinforced concrete columns before and after retrofitting.

\section{REPAIRING AND STRENGTHENING OF REINFORCED CONCRETE}

There are some previous study on retrofitting of concrete. Sadeghian, et al. (2010) conducted a research on experimental study of rectangular RC columns strengthened with CFRP composites under eccentric loading where the ultimate capacity load increased significantly compare to the original column. Kaminski \& Trapko (2005) conducted a research on retrofitting of column with CFRP where the capacity increased up to $37 \%$ and $49 \%$ compare to the original column. Nugroho (2002) conducted a research on retrofitting of column with CFRP where the strength increased up to $102.4831 \%$. In addition, obtainable increased of stiffness and reduced in deflection from the initial column. Adityo (2008) conducted retrofitting column by using wiremesh 3 $\mathrm{mm}, 4 \mathrm{~mm}$ and $5 \mathrm{~mm}$. The increase of capacity load obtained were about $150 \%, 143.63 \%$ and $190.28 \%$, respectively from initial column. Prakoso (2010) conducted a research strengthening and ductility of practical column strengthened using angle holes profile on eccentric load and found an increasing in stiffness up to $6000 \%$.

\subsection{Resin Concrete}

Polyester resin concrete consists of a filler material (aggregate) and a binder material (polymer). The most frequent type of polymer used is based on the four types of monomer or pre-polymer system: methyl methacrylate, polyester pre-polymer-styrene, epoxide pre-polymer hardener and furfryl alcohol. Compressive strength of the four types of monomers about 70-210 MPa, 50-150 MPa, 50-150 MPa, 48-64 $\mathrm{MPa}$ and 13-35 MPa, respectively (Lee, 2007). Bărbuţă \& Harja (2008) conducted a research on the characteristics of polymer concrete with epoxy resin in which $24 \%$ of the optimum polymer concentration, polymer mortar compressive strength between 51.1 to 69.1 MPa. Flexural strength of polymer mortar between 12.7 to $9.32 \mathrm{MPa}$ with a resin content of $24 \%$ with reduction of doses resin increase the flexural strength.

Jamshidi \& Pourkhorshidi (2011) conducted a research on modification of polyester resin on polymer concrete where polymer concentration used at $25 \%$ by mass of the aggregate. The compressive strength of polymer concrete has increased high in a short time, flexural strength of polymer concrete specimen almost a half from normal concrete and tensile strength of polymer concrete three times higher than normal concrete. Nugraha (2013) conducted a research on mechanical behavior of bamboo connections by bolts with filler resin with brand ponal epoxy resin. The compressive strength by using the resin obtained 88.92 MPa. Syukroni (2013) conducted a research on the physical and mechanical properties of resin mortar with variation of polyester resin at $5 \%, 10 \%, 15 \%, 20 \%, 25 \%$ where the mortar compressive strength about $0.09 \mathrm{MPa}, 0.47 \mathrm{MPa}, 5.8$ $\mathrm{MPa}, 36.03 \mathrm{MPa}$, and $113.77 \mathrm{MPa}$, respectively. Putra (2013) conducted a research on the physical and mechanical properties of polymer concrete with polyester resin variation at of $5 \%, 10 \%, 15 \%, 20 \%$, $25 \%$, and resulted resin concrete compressive strength about 9.71 $\mathrm{MPa}, 50.13 \mathrm{MPa}, 83.20 \mathrm{MPa}$, and 84.60 $\mathrm{MPa}$, respectively.

This research used a polyester resin with trademarks of SHCP (Singapore Highpolymer Chemical Products) WNC Type 2668 as the main ingredient for retrofitting columns that have been damaged. SHCP WNC 2668 mechanical characteristics are:

a) Specific gravity of liquid resin $=1.13 \mathrm{~kg} /$ liter

b) Flexural strength $=82.4 \mathrm{MPa}$

c) Tensile strength $=29.4 \mathrm{MPa}$

\subsection{Flexural Capacity of the Column}

Stress and strain diagrams are presented in Figure 1.

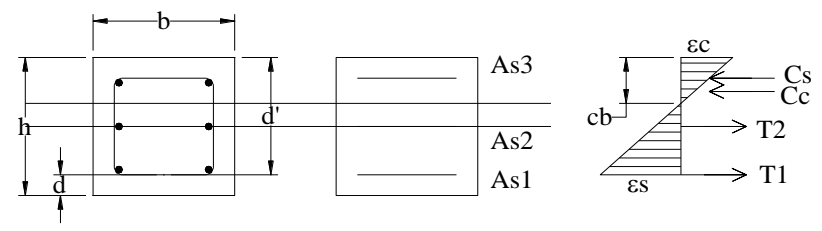

Figure 1. Column section, stress and strain diagram (Nawy, 2010).

Axial load in strain balanced condition:

$P_{b}=C_{c}+C_{s 3}-T_{s 1}-T_{s 2}$

Flexural strength (nominal moment) column can be calculated as follows:

$M_{n}=C_{c}\left(h / 2-\beta \mathrm{c}_{\mathrm{b}} / 2\right)+C_{s 3}\left(h / 2-d^{\prime}\right)+T_{s l}(h / 2-d)$ 


\subsection{Deflection and Curvature of Column}

According to Gere \& Timoshenko (1984), deflection $\delta_{\max }$ in the middle height of a column that receives the eccentric axial compressive load is as follows:

$\delta=\frac{P e h^{2}}{8 E I}$

According to (Park \& Pauly, 1974), column curvature $\varphi$ aquation is as follows:

$\varphi=\frac{1}{R}=\frac{2 \delta}{\delta^{2}+0.25 L^{2}}$

where, $R=\frac{\delta^{2}+0.25 L^{2}}{2 \delta}$

\subsection{Stiffness and Ductility of Column}

According to Gere \& Timoshenko (1984), relationship stiffness $K$ column as follows:

$$
K=\frac{P_{c r}}{\delta_{c r}}
$$

where, $K$ is column stiffness, $P_{c r}$ is critical axial load, and $\delta_{\text {cr }}$ is crtitical displacement.

According to Park \& Pauly (1974), ductility $\mu$ is difined as the amount of displacement ductility factor $\mu$, as follows:

$\mu=\frac{\Delta_{u}}{\Delta_{y}}$

where, $\mu$ is ductility, $\Delta_{u}$ is displacement (strain) at $20 \%$ decreasing from peak load, and $\Delta_{y}$ is displacement (strain) at yield of reinforcement.

\section{METHODOLOGY}

\subsection{Specimen}

Specimen consists of a preliminary specimen and column specimen. Specification of preliminary, data of column, and geometry of column specimen are given in Table 1, Table 2, and Figure 2, respectively.

\subsection{Implementation of Research}

The first stage of implementation stages of the research is making initial column specimen. Stage of making the initial column is reinforcement assembly and making of formwork, installation of strain gauge, casting the original column, curing process, painting and making the grid line, compressive strength of cylinders. The next stage is testing of the initial column. Initial column testing performed after the age of specimen 28 days. Specimen was set up in which all of the equipment for testing installed as hydraulic jack, load cell, data logger and LVDT. Arrangement and placement of equipment can be seen in Figure 3. After the initial column specimen test finished, retrofitting process will conduct. Retrofitting process in this step consist of pulverization the initial column, examination of the strain gauge, making formwork for column retrofit and casting of retrofit column. And the last stage is testing of retrofit column. For column retrofitting, KR-ii conducted after 28 days, while KR15 ii and KR-20ii performed after 7 days only. Before testing the retrofitting, column was painted and created the grid line. The specimen for retrofit column with the same for initial column was prepared.

Table 1. Specification of preliminary specimen

\begin{tabular}{lll}
\hline Test & Size & Number of Specimen \\
\hline Tensile strength of reinforcing bar & Average length of $50 \mathrm{~cm}$ & $\begin{array}{l}\text { Plain bar } \phi 8, \phi 10 \text { and } \\
\phi 12(\text { each of } 3 \text { bar }) \\
1 \text { cylinder, } 3 \text { cube, } 1 \\
\text { beam, }\end{array}$ \\
Bonding test between the old concrete with polyester resin concrete & $\begin{array}{l}\text { Cylinder }\left(150 \times 300 \mathrm{~mm}^{2}\right), \\
\text { cube }\left(50 \times 50 \times 50 \mathrm{~m}^{3}\right), \text { and } \\
\text { beam }\left(150 \times 150 \times 600 \mathrm{~mm}^{3}\right) \\
\text { Cylinder }\left(100 \times 200 \mathrm{~mm}^{2}\right)\end{array}$ & $\begin{array}{l}\text { a cylinders and } 4 \text { cube } \\
\text { and cube }\left(50 \times 50 \times 50 \mathrm{~m}^{3}\right)\end{array}$ \\
cylinder $\left(150 \times 300 \mathrm{~mm}^{2}\right)$ & 15 cylinders
\end{tabular}

Table 2. Data of column specimens

\begin{tabular}{llllll}
\hline Specimen & Cross Section & Bar & Shear & Eccentric load $(\mathrm{mm})$ & Retrofitting Types \\
\hline KN-i & $150 \times 150 \mathrm{~mm}^{2}$ & $4 \phi 10$ & $\phi 8-150$ & 50 & Normal concrete $f^{\prime}$ 20 MPa, become KR-ii \\
KN-15i & $150 \times 150 \mathrm{~mm}^{2}$ & $4 \phi 10$ & $\phi 8-150$ & 50 & Polyester resin concrete at 15\%, become KR-15ii \\
KN-20i & $150 \times 150 \mathrm{~mm}^{2}$ & $4 \phi 10$ & $\phi 8-150$ & 50 & Polyester resin concrete at 20\%, become KR-20ii \\
\hline
\end{tabular}




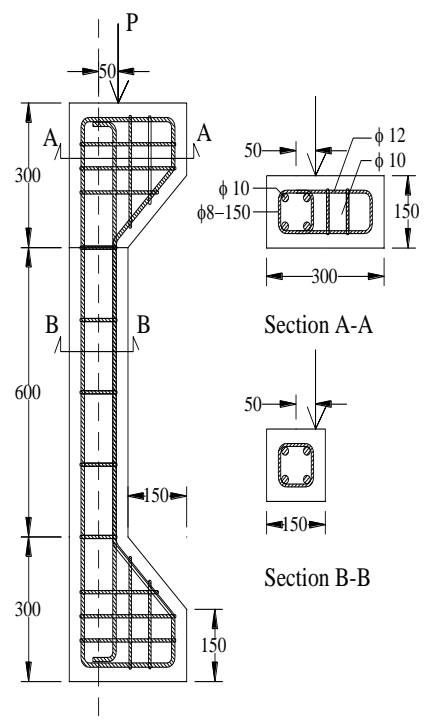

\section{a. Initial Column (kn) \\ b. Retrofit Column (KR)}

Figure 2. Geometry of column specimens

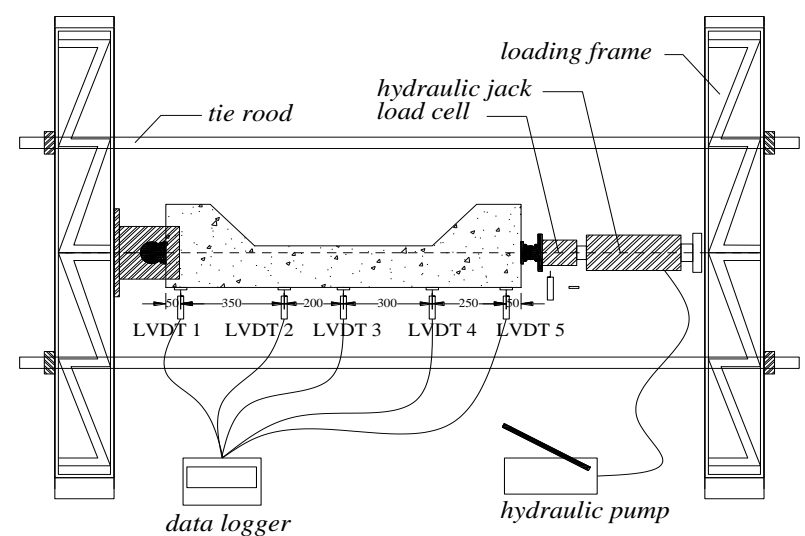

Figure 3. Test setup for column specimens
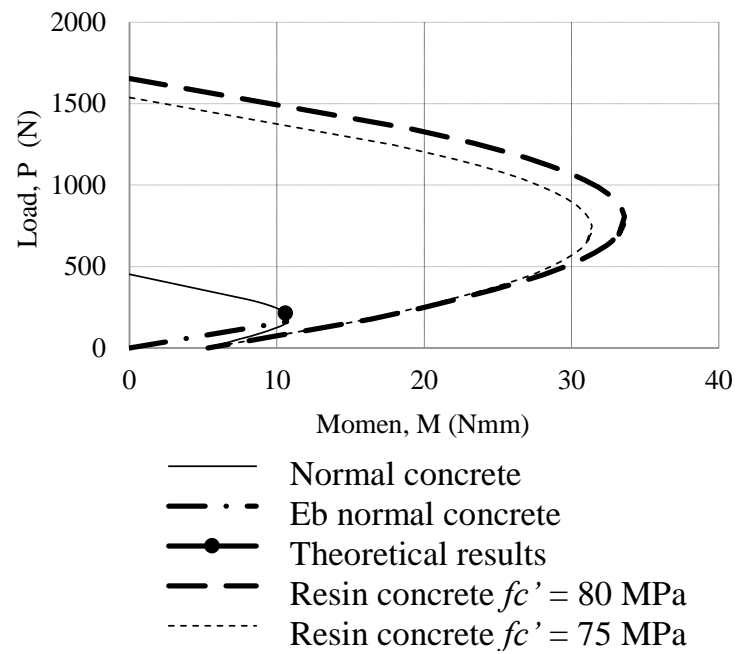

Figure 4. Column interaction P-M diagram for the determination of eccentricity

\subsection{Determination of Pattern Collapse Column}

Initial column be planned brittle failure occurs with a certain eccentricity. Having obtained an appropriate eccentricity, the retrofit columns will ductile collapse. Design method of determining the eccentricity done by Nawy Method. Trial and error is done by entering the value of $\mathrm{c}$ (press block) to obtain the proper eccentricity. The result obtained $\mathrm{e}=50 \mathrm{~mm}$ in the column interaction P-M diagram as shown in Figure 4 (Patah, 2013).

\section{RESULTS AND DISCUSSION}

\subsection{Preliminary Testing}

The result of preliminary testing as follows:

a) Tensile strength of reinforcing bar.

The test result for plain bar $\phi 8, \phi 10$, and $\phi 12$ for yield strength about $317.560 \mathrm{MPa}, 301.992 \mathrm{MPa}$ and $321.823 \mathrm{MPa}$, respectively. The modulus of elasticity is about $158780.101 \mathrm{MPa}, 180142.298$ $\mathrm{MPa}$ and $170361.198 \mathrm{MPa}$, respectively. While ultimate load strain about 0.002, 0.00168 and 0.00189 , respectively.

b) Bonding test between the previous concrete with polymer concrete.

Result of the bonding test between previous concrete with polymer concrete showed that failure occurs on previous concrete or normal concrete.

c) Compressive strength of polymer concrete mix design result

The average of the compressive strength for resin level at $10 \%, 15 \%$ and $20 \%$ for age of 7 days are about 42.501 $\mathrm{MPa}, 65.545 \mathrm{MPa}$ and $68.939 \mathrm{MPa}$, respectively. It seems that the level usage of resin in order to obtain optimum of the compressive strength at the level $15 \%$ and $20 \%$.

d) Compressive strength of concrete

The compressive strength test for normal concrete conducted at 7, 14, and 28 of age. The result of the compressive strength at 28 of age for normal concrete column is at $19.099 \mathrm{MPa}$ and for retrofitting concrete column at $20.290 \mathrm{MPa}$. Further, the average of elastic modulus for normal concrete column is at 20075.09 MPa, meanwhile for retrofitting concrete column at 21645.226 MPa. And the result of the testing polymer concrete of retrofitting column for resin level at $15 \%$ and $20 \%$ about $82.82 \mathrm{MPa}$ and $76.65 \mathrm{MPa}$, respectively. The average of elastic modulus is at $40808.49 \mathrm{MPa}$ and $37892.53 \mathrm{MPa}$, respectively. Further, the average of strain is about 0.0109 and 0.0110 , respectively. 


\subsection{Column Testing}

Testing of column is conducted in two steps, test for initial column and retrofit column. In order to know the increment of strength, performed column loading to initial column with preloading apply to initial column with limited reinforcing bar before yield point reached at 0.00134 . In addition, the observation of crack width up to $0.4 \mathrm{~mm}$ as a condition to conduct retrofitting to the conditions in the building structure, while retrofitting column testing conducted until $P_{u}$ load reached. The results of load and strain curve relationship for tensile bar of original column and retrofit column is presented in Figure 5.

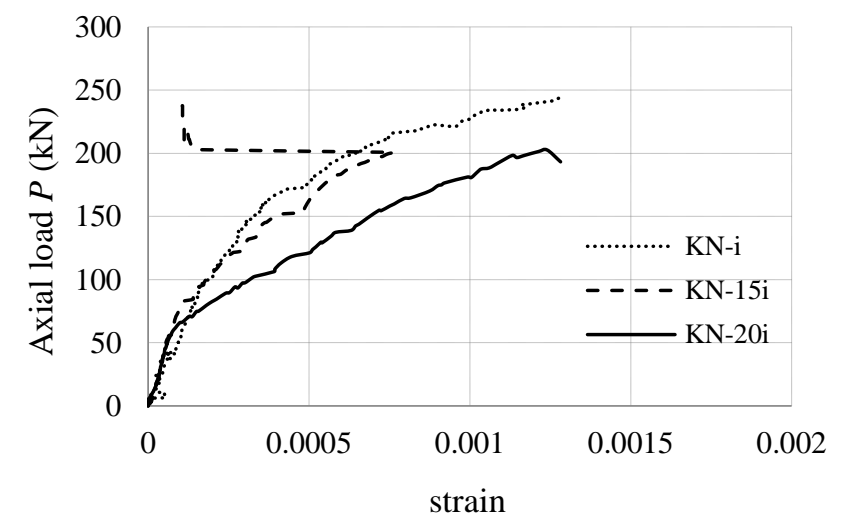

(a) Initial column

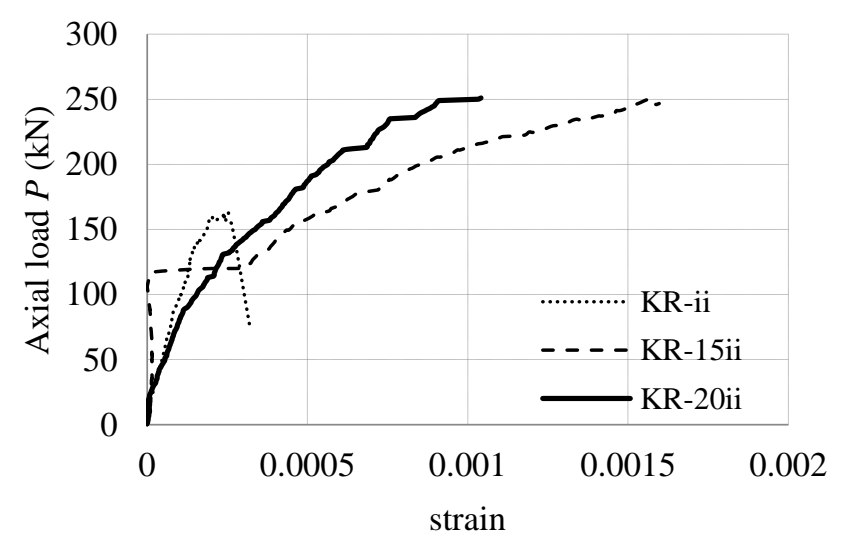

(b) Retrofit column

Figure 5. Load-strain tensile bar for initial column and retrofit column.

Figure 5a shows that the third initial column have first crack on load and deflection are almost same. First crack initiation load for $\mathrm{KN}-\mathrm{i}, \mathrm{KN}-15 \mathrm{i}$ and $\mathrm{KN}-20 \mathrm{i}$ about $99.3 \mathrm{kN}, 81.4 \mathrm{kN}$ and $101.7 \mathrm{kN}$ with deflection at $1.485 \mathrm{~mm}, 1.125 \mathrm{~mm}$ and $1.495 \mathrm{~mm}$, respectively. Preloading or maximum load apply for column KN-I, $\mathrm{KN}-15 \mathrm{i}$ and $\mathrm{KN}-20 \mathrm{i}$ about $245.5 \mathrm{kN}, 238.2 \mathrm{kN}$ and $202.6 \mathrm{kN}$.
4.3 Comparison of the capacity of the original column and retrofit column

Results of testing for original column and retrofit column of load $P_{c r}$ and $P_{\max }$ showed an increase in strength, as shown in Figure 6.

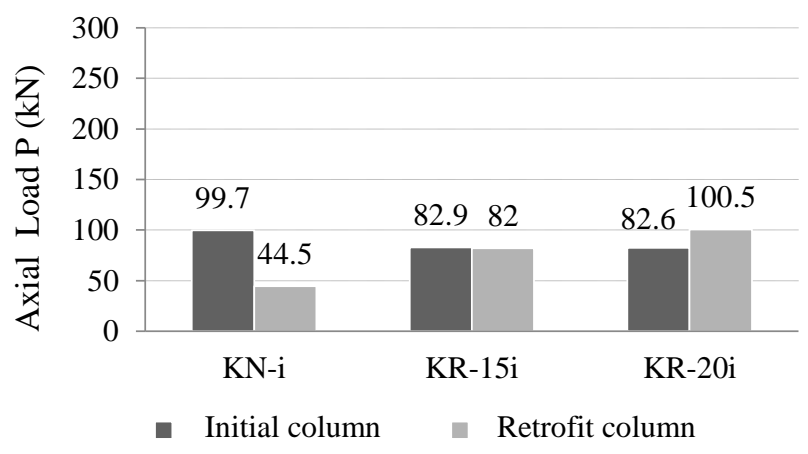

(a) $P_{\text {cr }}$ Load

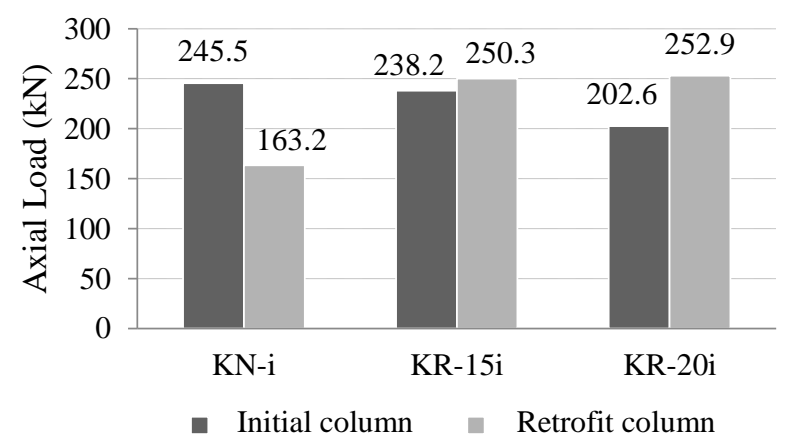

(b) $P_{\max }$ Load

Figure 6. Crack and maximum load for $\mathrm{KN}$ and $\mathrm{KR}$

Figure 6 shows that crack initiation load KR-ii and KR-15ii decreased of strength at $55.366 \%$ and $1.086 \%$ of the initial column, while KR-20ii increased of strength $21.671 \%$ of the initial column. For the current load conditions $P_{\max }$, KR-Ii decreased the strength of the original column up to $33.523 \%$. Instead there was an increase in the strength of KR-15ii and KR-20ii about $5.08 \%$ and $24.827 \%$ respectively of the initial column.

\subsection{Moment and curvature of column}

The results of the calculation of the moment and curvature for initial column and retrofit columns are shown in Table 3.

\subsection{Stiffness and Ductility of Column}

Stiffness values taken based on the comparison of the load deflection occurs when the first crack. The value is calculated only on retrofit column only, whereas the initial column is not calculated because the column 
has not reached the ultimate load. Stiffness and ductility result shown in Figure 7.

Table 3. Moment and curvature of initial column and retrofit column

\begin{tabular}{llllll}
\hline \multirow{2}{*}{ No. Specimen } & \multicolumn{2}{c}{ Moment $(\mathrm{kNm})$} & \multicolumn{2}{c}{ Curvature $(\mathrm{rad} / \mathrm{m})$} \\
\cline { 3 - 6 } & \multicolumn{2}{c}{ Crack } & Ultimate & Crack & Ultimate \\
\hline \multicolumn{2}{l}{ Initial column } & & & & \\
1 & KN-i & 5.143 & 13.199 & 0.035 & 0.084 \\
2 & KN-15i & 4.240 & 13.853 & 0.025 & 0.181 \\
3 & KN-20i & 5.292 & 11.048 & 0.035 & 0.101 \\
Retrofit Column & & & & \\
4 & KR-ii & 2.357 & 10.153 & 0.066 & 0.271 \\
5 & KR-15ii & 4.223 & 14.363 & 0.033 & 0.164 \\
6 & KR-20ii & 4.299 & 14.731 & 0.045 & 0.183 \\
\hline
\end{tabular}

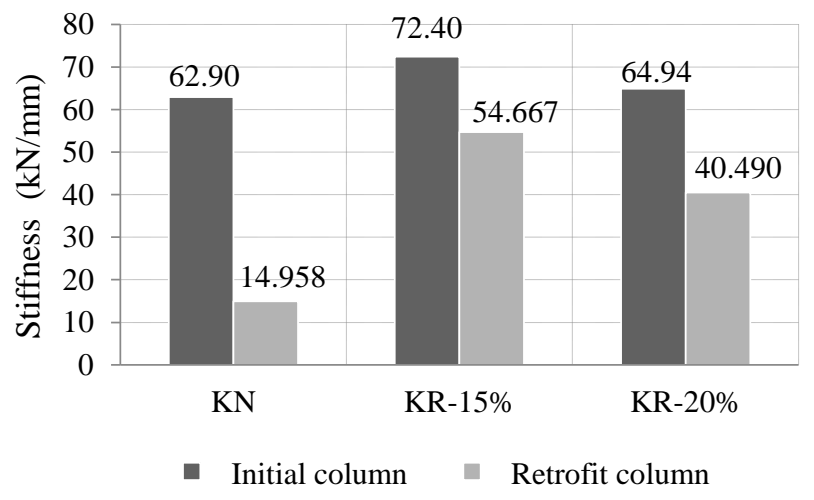

(a) Stiffness of columns

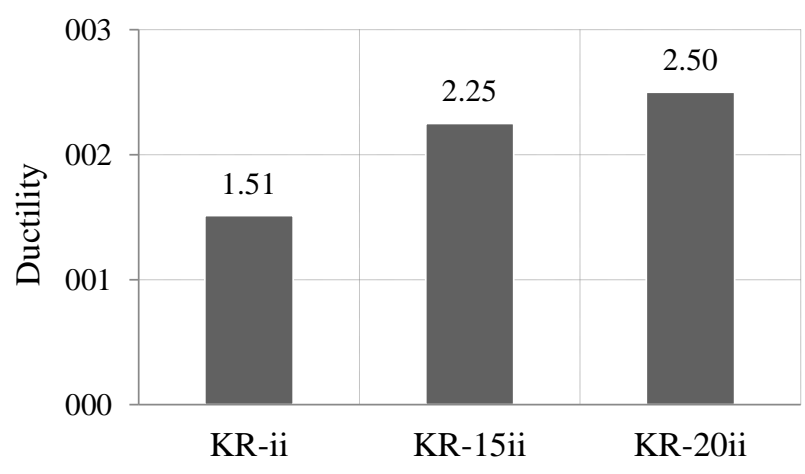

(b) Ductility of retrofit columns

Figure 7. Stiffness and ductility of columns.

Figure 7(a) shows that stiffness initial column tends same. However, stiffness of retrofit column decreased from the initial column. Reduction of stiffness retrofit column KR-ii, KR-15ii and KR-20ii about $76.22 \%$, $24.050 \%$ and $37.65 \%$, respectively from initial column. Figure $7 \mathrm{~b}$ shows that ductility of retrofitted column KR-ii, KR-15ii and KR-20ii about 1.512,
2.214 and 2.286, respectively. Method to evaluate the ductility is comparing the strain at the $20 \%$ decreasing from ultimate to strain of yielding of the reinforcement. Ductility of KR-ii is smaller than KR$15 \mathrm{ii}$ and KR-20ii. The ductility increment of KR-15ii and KR-20ii are about $46.48 \%$ and $51.208 \%$ respectively from KR-ii. This shows that the ductility of retrofit column with the addition of resin greater than retrofit column with normal concrete.

\subsection{Pattern of Cracking and Collapse}

At the initial column and retrofit column, the pattern of cracks that occur from the experimental results showed the same pattern of cracks that flexural cracks marked with horizontal cracks in tensile concrete side and then continues to spread in the direction of the press concrete side with increasing of load. Cracks will be more elongated and widened along with the increment of a load followed by spalling at the press area after reaching maximum load. Sketch crack patterns of the initial column and retrofit column are given in Figure 8.

\subsection{Comparison of the Analytical and Experimental}

The comparison between the results of the analytical load capacity (Nawy methods and Whitney methods) and experiments are given in Table 4.

Table 4. Results of experimental and analytical load capacity

\begin{tabular}{lllll}
\hline \multirow{2}{*}{ Specimen } & \multicolumn{2}{l}{ Analytical $P_{\max }(\mathrm{kN})$} & \multicolumn{2}{c}{$\begin{array}{c}\text { Experiment, } P_{\max } \\
(\mathrm{kN})\end{array}$} \\
\cline { 2 - 5 } & $\begin{array}{l}\text { Nawy } \\
\text { method }\end{array}$ & $\begin{array}{l}\text { Whitney } \\
\text { method }\end{array}$ & $\begin{array}{l}\text { Initial } \\
\text { column }\end{array}$ & $\begin{array}{l}\text { Retrofit } \\
\text { column }\end{array}$ \\
\hline KNi to KRii & 211.725 & 195.038 & 245.5 & 163.2 \\
KN-15i to KR- & 211.725 & 195.038 & 238.2 & 250.3 \\
15ii & & & & \\
KN-20i to & 211.725 & 195.038 & 202.6 & 252.9 \\
KR20ii & & & & \\
\hline
\end{tabular}

Table 4 is shown that the capacity ultimate load changed after retrofitting for KR-ii, KR-15ii and KR$20 \mathrm{ii}$ to Nawy method about $-22.92 \%$; $18.22 \%$; $19.45 \%$, respectively. While the Whitney method about $-16.32 \%$; $28.33 \%$; and $29.66 \%$, respectively.

Column interaction diagram comparison between normal concrete and polyester resin concrete (resin content of $15 \%$ and $20 \%$ ) are presented in Figure 9. It shows the experimental results as expected which will collapse when the attraction P-M continues until it reaches the point of the curved lines PM for polyester resin concrete. 

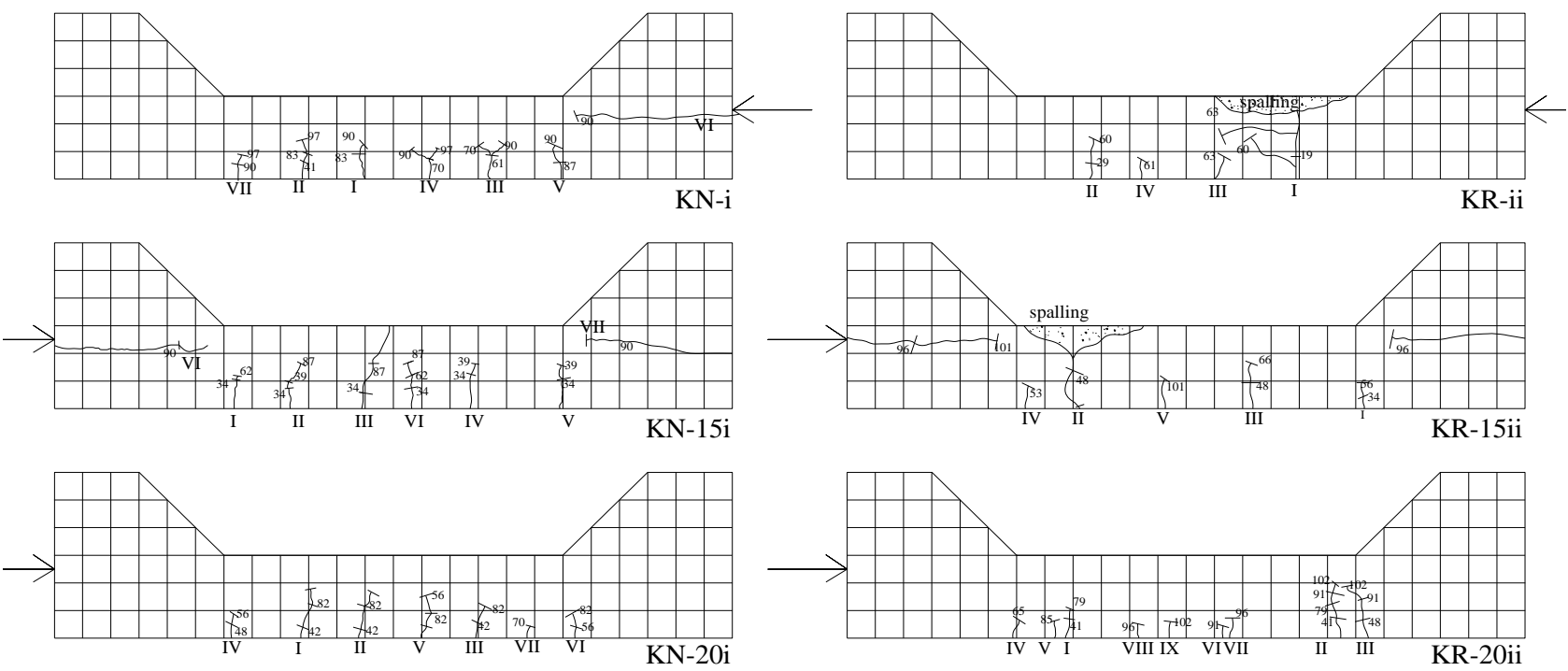

Figure 8. Sketch crack patterns of specimen.
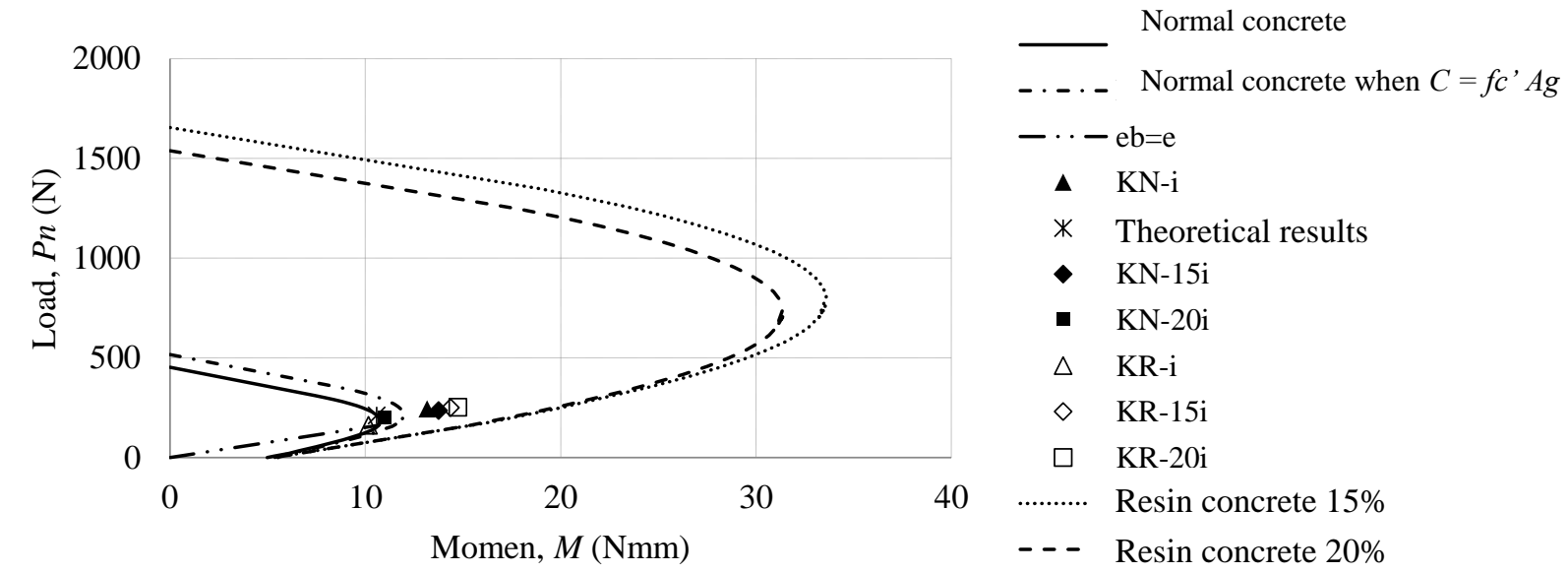

Figure 9. Column interaction P-M diagram analytical versus experiment results

\section{CONCLUSIONS}

Based on the analysis and discussion that has been done, the following conclusions are drawn:

a) The optimum content of resin to be use $20 \%$ because easy to work compared to $15 \%$ resin.

b) Compressive strength of polyester resin concrete at level $15 \%$ and $20 \%$ about $82.82 \mathrm{MPa}$ and 76.65 $\mathrm{MPa}$, elastic modulus about $40808.49 \mathrm{MPa}$ and $37892.53 \mathrm{MPa}$, and strain about 0.0109 and 0.0110 , respectively.

c) Application of normal concrete does not increase the strength of column from initial column after retrofitting, whereas application of polymer resin concrete could restored and even increased the strength of column. The changes of the strength column KR-ii, KR-15ii, and KR-20ii about $33.523 \% ; 5.08 \%$; and $24.827 \%$ respectively from the initial column. d) Stiffness value decreased on retrofit column against initial column for KR-ii, KR-15 ii and KR$20 \mathrm{ii}$ about $76.22 \%$; $24.50 \%$ and $37.65 \%$, respectively.

e) Ductility values for retrofit column KR-ii, KR-15ii and KR-20ii about $1.51 ; 2.0 ; 2.25$; and 2.5, respectively.

f) The use of polyester resin concrete can change the pattern of collapse of brittle to ductile columns.

g) The changes of ultimate load capacity KR-ii, KR15ii, and KR-20ii to Nawy Methods about $26.54 \% ; 12.66 \%$; and $13.83 \%$, respectively. While Whitney Methods are about $-17.68 \% ; 26.25 \%$; and $27.56 \%$, respectively.

\section{ACKNOWLEDGMENTS}

This study is funded via Indonesian Education Scholarship (Lembaga Pengelola Dana Pendidikan/LPDP) 2013. The support of LPDP is 
acknowledged with thanks. The authors are also thankful to the lecturers, examiners, laboratory, and colleagues who have helped in the completion of this research.

\section{REFERENCES}

Adityo, R. S. (2008). Pengaruh Penggunaan Wiremesh dalam Perbaikan Kolom Pendek Penampang Persegi Akibat Beban Eksentris 0,75h [Effect of Wiremesh Application on the Repairment of Short Rectangular Column due to Eccentric Load 0.75 h]. Thesis, Universitas Gadjah Mada, Yogyakarta.

Bărbuţă, M., \& Harja, M. (2008). Experimental Study on The Characteristics of Polymer Concrete with Epoxy Resin. Buletinul Institutului Politehnic Din IASI.

Gere, \& Timoshenko. (1984). Theory of Elastic Stability (International Student Edition ed.). Tokyo, Japan: McGreaw-Hill Kogahusa.

Jamshidi, M., \& Pourkhorshidi, A. R. (2011). Modified Polyester Resins as an Effective Binder for Polymer Concretes. Journal of Materials and Structures(45), 521-527.

Kaminski, M., \& Trapko, T. (2005). Experimental Behaviour of Reinforced Concrete Column Models Strengthened by CFRP Materials. Journal of Civil Engineering and Management, XII(2), 109-115.

Lee, E. H. (2007). Application of Polymer in Concrete Construction. Universiti Teknologi Malaysia, Malaysia.

Nawy, E. G. (2010). Beton Bertulang Suatu Pendekatan [An Approach of Reinforced Concrete]. Institut Teknologi Sepuluh Nopember. Bandung: Rifka Aditama.
Nugroho. (2002). Kuat Batas Lentur Kolom Beton Bertulang Segi Empat dengan Perkuatan CPRF Wrap [Ultimate Bending Strength of Rectangular Column with Reinforcement of CPRF Wrap]. Thesis, Universitas Gadjah Mada, Yogyakarta.

Park, P., \& Pauly, T. (1974). Reinforced Concrete Structure. New York, London, Sidney, Toronto: A Wiley-Interscience Publication.

Patah, D. (2013). Perbaikan Dan Perkuatan Lentur Kolom Dengan Beton Resin Poliester (polyester Resin Concrete) [Repairment and Bending Reinforcement of Column with Polyester Resin Concrete]. Yogyakarta: Universitas Gadjah Mada.

Prakoso, G. (2010). Perkuatan dan Daktalitas Kolom Praktis Diperkuat dengan Profil Siku Berlubang pada Beban Eksentris [Reinforcement and Ductility of Practical Column Reinforced by L Hollow Profile on Eccentric Load]. Thesis, Universitas Gadjah Mada, Yogyakarta.

Putra, K. A. (2013). Sifat Fisik dan Mekanik Beton Polimer dengan Variasi Resin 5\%, 10\%, 15\%, $20 \%$ dan 25\% [Physical and Mechanical Characteristics of Polymer Concrete with 5\%, 10\%, 15\%, 20\% and 25\% Resin]. Universitas Gadjah Mada, Yogyakarta.

Sadeghian, P., Rahai, A. R., \& Ehsani, M. R. (2010). Experimental Study of Rectangular RC Columns Strengthened with CFRP Composites Under Eccentric Loading. Journal of Composites for Construction, XIV(4), 443-450.

Syukroni, A. (2013). Sifat Fisik dan Mekanik Mortar Polimer dengan Variasi Resin 5\%, 10\%, 15\%, 20\%, dan 25\% [Physical and Mechanical Characteristics of Polymer Mortar with 5\%, 10\%, 15\%, 20\% and 25\% Resin]. Universitas Gadjah Mada, Yogyakarta. 